\title{
Forestry in Mauritius
}

CONSIDERABLY more than twenty-five per cent of the island of Mauritius is occupied by forests and rocky mountains which lie outside the cultivated area. As is pointed out in the Annual Report of the Forest Department of Mauritius for 1930, the great density of population, the small area of the forests (Government forests, Crown and other forest lands, total 92,050 arpents or about 95,732 acres) and the demands made upon them, the many uses to which wood is put, and the local dependence on imported timber, all point to the vital importance of forestry in the island. Since the forests lie mainly on the top and slopes of the central plateau, from which all the important rivers run, it is obvious that their preservation is equally vital to the maintenance of the premier industry of sugar cultivation, in order to prevent erosion and its destructive aftermath, and to secure the maintenance of water supplies, and so forth.

During the year effect was given to a scheme of reorganisation of the Department, in order to introduce better methods of control and to permit of future development. It is unfortunate that this scheme, which reflects the highest credit upon its authors, should have so nearly coincided with present financial stringency. Nevertheless, when the chief commercial interest of the Colony is so intimately bound up with its forests, it may be confidently expected that the recognition accorded to the importance of the Forest Department may not be withdrawn owing to what, it may be hoped, is a temporary financial embarrassment.

The climate of the central plateau of the island is cool, windy, and wet. The two southern masses of forest are by far the largest, and from them the Grand Bassin Division (30,000 arpents) and the Midlands Division (21,000 arpents) have been formed (1 arpent equals 1.044 English acres). The northern block of forest comprises the Nouvelle Découverte Division, of about 5700 arpents. The Divisions are mainly State forest, with some privately owned mountain reserves along the boundaries. Grand Bassin Division contains 2800 arpents of mountain reserves, Midlands Division 500 arpents, and Nouvelle Découverte Division 1000 arpents.

About one-half of the staff is engaged outside the forests in protecting the mountain, river, and road reserves, administering the laws governing those reserves, working the small isolated State forests, and inspecting leased Crown lands, notably a strip of land round the coast, known as Pas Géométriques.

Forest management is under the control of a Forest Board, which held seven meetings during the year, the subjects under consideration consisting of the working of the land purchase scheme, the management of the mountain reserves, and the forms of lease for the Pas Géométriques.

A considerable amount of forest survey work was undertaken, 500 miles of boundary lines cleaned of weeds, and stock maps of the growing stock on 3470 arpents of forest prepared. Roads and a tramway line were also under construction to facilitate the extraction of timber and fuel.

Experiments in afforestation work and the rearing of exotics have been in hand for some years, and recently this work has made great strides. Wide spacing was formerly made use of in plantations, but the policy is now to plant closer, and a considerable amount of work in filling up the old wide-spaced plantations has had to be undertaken in order to obtain satisfactory crops. Tending the new plantations is also given careful attention, and plantation control books have been introduced, the officer concerned filling up data of growth and so forth twice in the year-a most excel- lent provision. On the subject of this work, the conservator, Mr. G. N. Sale, writes : "During the past, fifty years numerous species [of exotics] have been tried, and many found to be suitable for plantations. This work was continued in 1930, and success was obtained in the nurseries with Pinus caribcea, which germinated and grew even better than Pinus toda. It is to be hoped that this valuable tree will prove as vigorous in the forest as in the seed-bed. Pinus palustris formed luxuriant foliage, but no leader. Pinus sylvestris, Sequoia sempervirens, and Ormosia semicastrata failed in the Nursery."

Animals, especially deer, and weeds appear to be the chief dangers which the forests have at present to fear. It is said that "the number of deer is kept as high as possible by the Lessees of the Shooting Rights over nearly the whole of the State forests ". It is not stated what rent is obtained from the lessees ; in the latter part of last century, when the King of Saxony desired to have an excessive number of deer maintained in the State forests, he paid a considerable rent for the feeding of the animals during the winter months, and for excessive damage done, in addition.

Under the heading of utilisation, some interesting information is given on the subject of timber and fuel. Most of the timber obtained during the year came from Belle Rive, in Midlands Division. " The timber was extracted partly in the form of logs, which were sent to the Match Factory. Pine scantlings were sold to the Harbour Engineer, who worked the timber, soaked it in fuel oil and used it in the Granary. This form of impregnation was adopted by the Forest Department, and the results will be watched with interest. If the Chinese Pine timber can easily be rendered immune from the attacks of White Ants, the plantations made from 1885 onwards should supply material of the greatest value to the Colony during the next twenty years. The Pine timber proved fairly satisfactory in seasoning, and did not split and twist to any. great extent, but the timber of Eucalyptus robusta was very difficult to season." The forest felled was apparently patchy; eucalyptus had outgrown the pine, developing large spreading branches. The timber not being straight-grown, it warped and split badly, especially when sawn into boards and planks. Straightgrown eucalyptus, especially $E$. tereticornis and 'E. hybrid', would, it is believed, yield very good boards when carefully seasoned. It is stated that the demand for indigenous timber is steady, if not large; 'plantation timber' of exotic species is much less popular. "It will not be possible to produce any considerable supply of indigenous timber, and it is hoped that when the public becomes accustomed to well seasoned exotic timber, this prejudice will disappear."

Whilst it is obviously to the interest of the Colony to endeavour to raise in plantations such a proportion of exotic timber material as will reduce the imports, yet the neglect to maintain and obtain the regeneration of at least a portion of the indigenous forests would not, we believe, be in the true interests of the Colony or its future. An entire reliance on introduced species is dangerous, and is probably uneconomic in the long run.

A suggestion might be proffered on the subject of the tabular statements in the appendix series. These are not in some cases easy to follow, and in Appendix 9 no totals are given. A statement of the imports of timber and other forest produce into the Colony would be useful. With this minor criticism, it may be said that the Report under review has many points of unexpected interest, and reflects creditupon the Governor the Forest Board, and the Conservator. 